\title{
Making Virgin Coconut Oil (VCO) with Fermentation Process Using Fermipan and Addition of Pineapple Extract
}

\author{
Kindriari Nurma $\mathrm{W}^{*}$, Robet Wilya VP, Dean Perdana \\ Chemical Engineering Department, Engineering Faculty, Universitas Pembangunan Nasional "Veteran" Surabaya, \\ East Java, Indonesia
}

\author{
* Correspondence Author \\ E-mail: \\ kindrinurma@gmail.com
}

\begin{abstract}
Virgin coconut oil (VCO) is a form of processed coconut meat that has recently been produced for commercial use. Virgin coconut oil or pure coconut oil is the result of processed coconut that is free of trans-fatty acid (TFA) or trans-fatty acids that are easily digested and oxidized by the body to prevent accumulation in the body. Trans fatty acids can occur due to the hydrogenation process, so as not to undergo the hydrogenation process, the extraction of coconut oil is carried out by the fermentation process. This research was conducted by the Fermentation method using Fermipan as a microbe and the addition of the bromelin enzyme from pineapple extracts. The variables in this study were $100 \mathrm{ml}$ of coconut milk volume, $\mathrm{pH}$ 4 , and fermipan weight 0.2 gr. The variables implemented were pineapple extract volume (20, $25,30,35,40) \mathrm{ml}$, fermentation time $(18,24,30,36,42)$ hours. Analysis of VCO results compared with VCO SNI, namely the content of water content, free fatty acid numbers, saponification numbers, and iodine numbers. Optimum VCO results were obtained at 30 hours fermentation time and $30 \mathrm{ml}$ pineapple extract which produced $35 \mathrm{ml}$ rendamen, water content 0.08 , free fatty acid numbers 0.1 , saponification number 72.9 , and Iodine number 26.65 .
\end{abstract}

Keywords: VCO, fermentation, pineapple extract, fermipan

\section{Introduction}

Virgin coconut oil (VCO) is a form of processed coconut meat that has recently been produced for commercial use. Virgin coconut oil or pure coconut oil is the result of processed coconut that is free of trans-fatty acid (TFA) or trans-fatty acids that are easily digested and oxidized by the body to prevent accumulation in the body (Aditiya, et al., 2014). These trans-fatty acids can occur as a result of the hydrogenation process so that they do not undergo the hydrogenation process, the extraction of coconut oil is carried out by a fermentation process (Andaka \& Arimsari, 2016). Currently, many people are aware of health, they start with a healthy lifestyle and healthy food, VCO has been widely known. benefits for health, the use of VCO, among others, in the form of cooking oil, cosmetics, and antioxidants. The reason VCO is used for health is that coconut oil is high in lauric acid and other ingredients.

In this study, a combination method of fermentation using fermipan and the addition of pineapple extracts were applied to the extraction and manufacture of VCO. Making VCO by enzymatic and fermentation methods, where the source of the protease enzyme is obtained from the juice of pineapple.

The fermentation method uses Fermipan as a microbe and the enzymatic method in making VCO uses coconut milk as the main ingredient and enzymes as auxiliary ingredients. Bromelain enzymes hydrolyze protein, making the coconut milk emulsion unstable so that the oil and water phases are separated. (Winarni, et al., 2012)

Evaluation of the quality of VCO results is carried out by comparing the quality of VCO produced with the VCO quality standards that have been established in the Indonesian National Standard, namely the

How to cite:

Numa-K, K., Wilya-VP, R., \& Perdana, D. (2020). Making Virgin Coconut Oil (VCO) with fermentation process using fermipan and additional of pineapple extract. $1^{\text {st }}$ International Conference Eco. Innovation in Science, Engineering, and Technology. NST Proceedings. pages 238-242. doi: 10.11594/ nstp.2020.0537 
moisture content of $\mathrm{VCO}(0.2 \%)$, the free fatty acid number (maximum $0.2 \%$ ) and the saponification number ( 250-260 mg KOH / g sample). The benefits of this research are expected to produce a better method, raw materials that are easily available, affordable, and environmentally friendly in making VCO.

\section{Research Method}

The materials used in this study include Coconut Milk, Fermipan, Pineapple Extract, Water, PP Indicator, Oxalic Acid, Alcohol, $\mathrm{NaOH}, \mathrm{KOH}$.

Variable Conditions determined Coconut cream volume $100 \mathrm{ml}, \mathrm{pH} 4$, room temperature $\pm 30^{\circ} \mathrm{C}$. Fermipan 0.2 g, Variables carried out, Volume of Pineapple Extract $(20,25,30,35,40) \mathrm{mL})$, Fermentation Time $(18$, 24, 30, 36, 42) hours.

1. Pineapple Extract Making :

Young pineapple peeled, washed, and cut into small pieces then weighed 500gr. After that, it is blended and filtered and then collected into a clean container. The pineapple juice is transferred in a bottle and stored in the refrigerator for one night.

2. Making grated coconut :

Coconut is broken into several pieces. The fruit is shredded, the grated product is weighed to be used as needed.

3. Making VCO coconut oil :

Add $1 \mathrm{~kg}$ of grated coconut to $900 \mathrm{ml}$ of warm water. The addition of warm water was carried out in stages 3 times, namely $300 \mathrm{ml}, 300 \mathrm{ml}$, and $300 \mathrm{ml}$. After adding warm water, the coconut was squeezed so that coconut milk was obtained. The coconut milk is placed in the prepared container. After the coconut cream and water are separated (allowed to separate for about 1 hour) the coconut cream is separated from the water. Cream of coconut milk volume $100 \mathrm{ml}, \mathrm{pH}$ 4. Fermipan $0.2 \mathrm{~g}$, Variables carried out, Volume of Pineapple Extract $(20,25,30,35,40) \mathrm{ml}$, Fermentation Time $(18,24,30,36,42)$ hours

Checking the fermentation process is carried out based on a predetermined time.

Analysis :

Rendement: The calculation of the yield of oil produced in this study was carried out by determining the quantity ratio between the weight of the oil produced (product) and the initial weight of the raw material used (coconut cream) multiplied by one hundred percent.

Several Free Fatty Acids: 10 grams of VCO was put into Erlenmeyer, then $50 \mathrm{ml}$ of $95 \%$ neutral alcohol was added and then heated for 10 minutes. After that, it is cooled then added with phenolphthalein indicator. titrated using a previously standardized $0.1 \mathrm{~N} \mathrm{NaOH}$ solution. The titration is discontinued if pink appears and does not disappear for 30 seconds.

Determination of Iodine Numbers: As much as 0.5 grams of VCO produced is weighed then put in Erlenmeyer Add $10 \mathrm{~mL}$ of chloroform and $25 \mathrm{~mL}$ of iodine bromide reagent and then stored in a dark place for 12 hours. Then add $10 \mathrm{ml}$ of $15 \% \mathrm{KI}$ solution and $100 \mathrm{~mL}$ of boiled distilled water into the solution. And immediately titrated with the sodium-thiosulfate solution $\left(\mathrm{Na}_{2} \mathrm{~S}_{2} \mathrm{O}_{3} 0.1 \mathrm{~N}\right)$ until the yellow color disappears. Then added with $2 \mathrm{ml}$ of starch and re-titrated with $\mathrm{Na}_{2} \mathrm{~S}_{2} \mathrm{O}_{3} 0.1 \mathrm{~N}$ until the blue color is gone. A blank solution made from $25 \mathrm{ml}$ of iodine bromide reagent and added with $10 \mathrm{ml}$ of $15 \% \mathrm{KI}$ was diluted with $100 \mathrm{ml}$ of distilled water that had been boiled and titrated with sodium thiosulfate solution. The amount of sodium thiosulfate for the titration blank minus the actual titration is the equivalent of the amount of iodine bound by fat or oil. 


\section{Result and Discussion VCO yield}

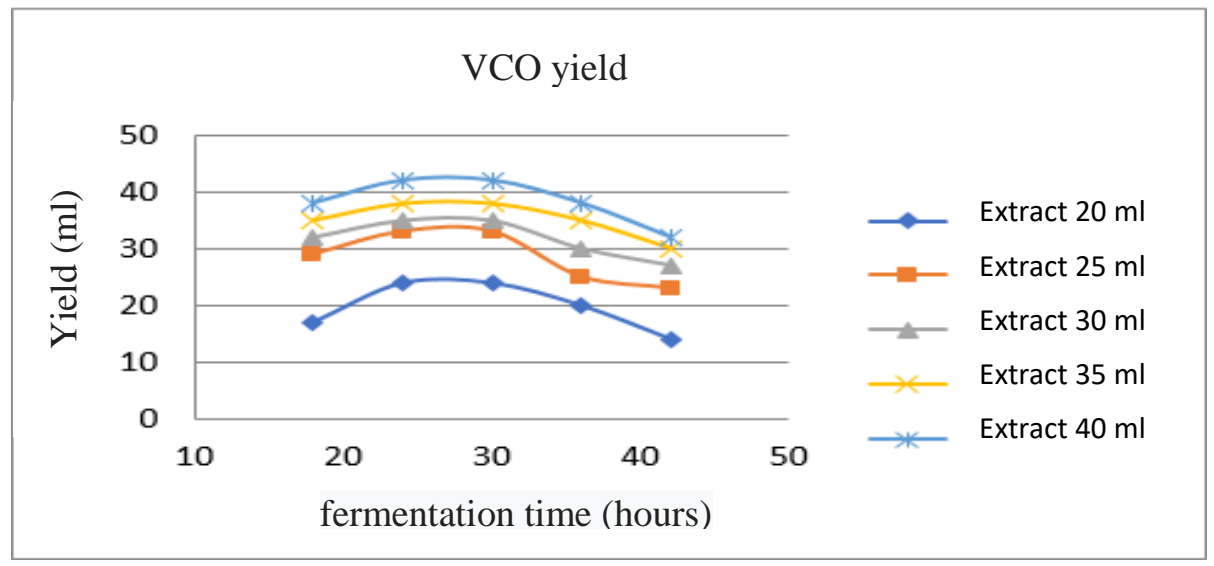

Figure 1. VCO yield

The VCO yield was increased at 18 hours and 24 hours. Then the oil produced was still obtained at 24 hours and 30 hours. Then the oil obtained decreased at 36 hours and 42 hours. According to Artini (2016) the coconut milk emulsion system consists of a mixture of water, oil, and protein. When the emulsion is broken down by enzymes, the mixture will be fragmented (broken down) into oil fraction, protein fraction, and water fraction. The results showed that the higher the volume of pineapple used, the higher the oil yield was obtained, this was due to the increasing number of protein as a coconut milk emulsion stabilizer that could be broken down, but the addition of certain pineapple volumes, namely the addition of $35 \mathrm{ml}$ and 40 ml pineapple volumes decreased.

\section{Analysis of free fatty acid}

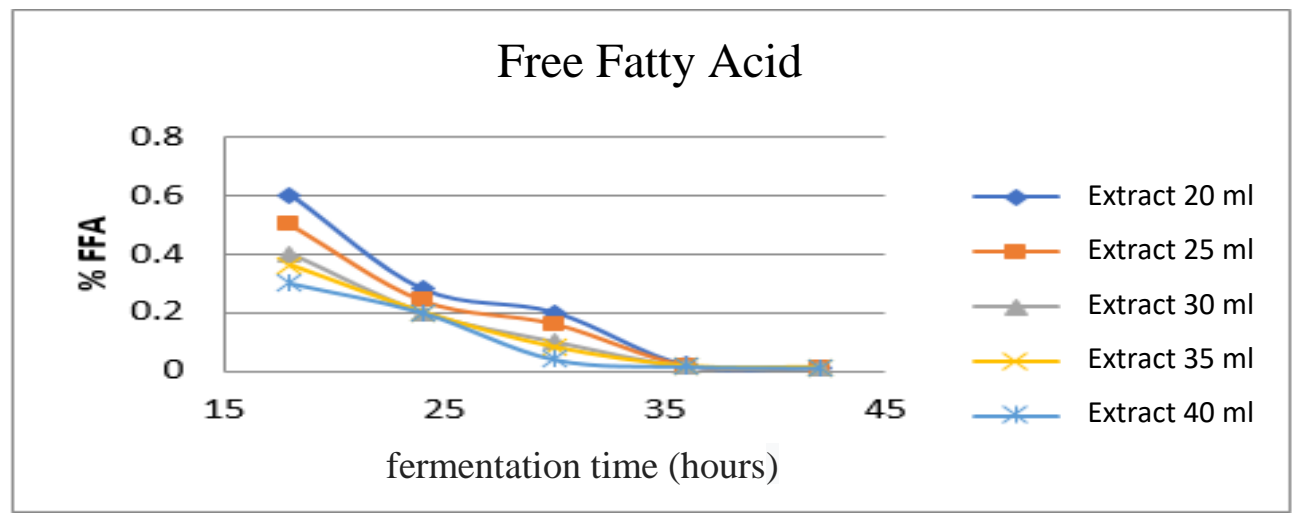

Figure 2. Free fatty acid analysis

Analysis of free fatty acids showed a decrease at each time. According to Artini (2016), the main factors causing oil hydrolysis are water and the enzyme lipase. In the presence of water, fat can be hydrolyzed into glycerol and fatty acids. Because the higher the concentration of the protease enzyme used causes the lower the water content of the oil, which results in a lower \% FFA VCO. According to Ngatemin \& Isworo (2013), free fatty acids are a precursor to hydrolysis rancidity. Which can be viewed based on the fermentation process, the microbes will break down the fatty acid molecules which cause the fatty acids to be hydrolyzed into glycerol, where the longer the fermentation process takes place, the less free fatty acids 
contained in VCO. So that the lower the free fatty acids, the better the quality of the oil produced. (Cahyani 2014)

Analysis of iodine number

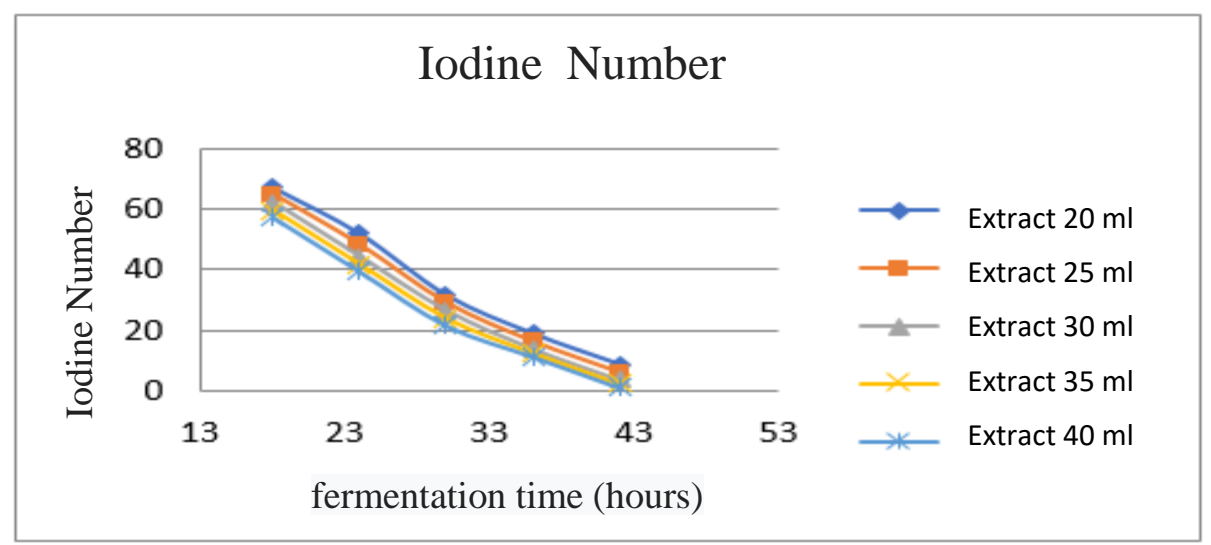

Figure 3. Iodine number analysis

The amount of iodine absorbed is the number of double bonds or unsaturated bonds. According to Winarni et al., (2012), the increase in iodine number is not due to the increase in double bonds in oil but because non-oil compounds containing double bonds such as polymers, proteins, hydrocarbons, glycosides, and $\beta$-carotene have been separated, this is the same as stated by Nafiun (2013). Where in determining the iodine number, the objective is to determine the number of double bonds contained in fatty acids. It can be reported that the longer the fermentation process, the less iodine number is obtained so that the fewer double bonds are contained in fatty acids. The less iodine number, the less saturated the fatty acids are. In the SNI calculation, the appropriate data was obtained at 42 hours with the addition of $20 \mathrm{ml}$ to $40 \mathrm{ml}$ extract.

\section{Conclusion}

The longer the fermentation time, the lower the \% FFA value, the smallest \% FFA value obtained when the fermentation time was 42 hours

\section{Acknowledgment}

We would like to thank our fellow researchers at the University of Pembangunan Nasional "Veteran" East Java, the entire team at the lab research that has helped the completion of this research, and the Faculty of Engineering which has provided an opportunity to use laboratory equipment.

\section{References}

Aditiya, R., Rusmarilin, H., Limbong, L. (2014). Optimization of Making Virgin Coconut Oil (VCO) with the Addition of Yeast Bread (Saccharomycesb Cerevisiciae) and Long Fermentation with VCO. USU Medan Food and Agriculture Engineering Department, 2(2), $1-6$

Andaka, G., Arimsari, S. (2016). Taking Coconut Oil with the Fermentation Method Using Baker's Yeast.. Journal of Chemical Engineering, 10(2), $1-5$

Artini. (2016). Complete Definition of Fermentation and Examples. Retrived from www.artiiini.com/2016/05/ understanding-fermentationcomplete.html on March 2, 2018

Cahyani, I. (2014). Determination of Acid Numbers (Free Fatty Acid Levels). Retrived from Http://kimiaterpadusmakma20143b10.blogspot.co.id/2014/09/title-acids-levels-free-fatty-acids.html on March 252018

Nafiun. (2013). Acid Numbers. Retrived from http://www.nafiun.com/2013/10/number-acid-ester-iodin-number.html on March 25

Ngatemin., N., \& Isworo, J. (2013). The Effect of Long Fermentation on Virgin Coconut Oil Production on Physical, Chemical, and Organoleptic Properties. Food Technology, University of Muhammadiyah Semarang, 4(8), 13-20 
Silaban, R., Manullang, R., Hutapea, V. (2014). Making Virgin Coconut Oil (Vco) Through a Combination of Fermentation and Enzymatic Techniques Using Pineapple Extract. Medan: Department of Chemistry-FMIPA, State University of Medan

Winarni, Effendi, A, Sumarni, W. (2012). Optimizing the Use of Bromelin Enzymes from Pineapple Weed Extract in Making Coconut Oil. Semarang: Department of Chemistry, State University of Semarang 